\title{
Theoretical and Methodological Conceptualization of the Western Historiosophical Thinking
}

\author{
Viktor Eduardovich Lebedev \\ Ural Federal University named the first President of Russia B.N. Yeltsin, 19, Mira street, \\ Ekaterinburg, Sverdlovskaya Region, 620002, Russian Federation
}

\section{Doi:10.5901/mjss.2015.v6n4s1p406}

\section{Abstract}

\begin{abstract}
The object of research is the historical dimension of human existence in the context of the dynamics of Western thinking. The author analyzes the major trends in the development of Western historiosophical mind. The theory of historical knowledge historical epistemology - was used to research the problem. It was used as a ground to show how fundamental issues of the human natural being were raised and solved: in particular, the issues of the ontological status of history (the "what" of the history), of the mechanisms of its functioning (the "how" of the history), of its direction (the "where" of the history), of its unity and multiplicity (the "how much" of the history), of its spatiotemporal certainty (the "where" and the "when" of the history). All the variety of these issues that sound in the context of philosophical reflection concerning the historical process comes together to a focus in the formulation of the problem of the meaning and purpose of history. The author concludes that the philosopher does not deliberately invent the theoretical matrix of understanding the history, but finds it in the conscious of the contemporary era and uses to construct meaningful structures of historical movement. In accordance with the dominant of the social consciousness of a certain era - in the framework of a theoretical understanding of history - its "dominant" historiosophema emerges. Their research is important in the theory of historical knowledge.
\end{abstract}

Keywords: philosophy of history, historiosophy, social consciousness, historical space and time, historiosophema, science.

\section{Introduction}

\subsection{Introduction to the Problem}

Certain dynamics in understanding history can be traced in the history of Western thinking, which unlike the Eastern thinking primarily addressed the natural (historical) problems of human existence rather than transphysical (metahistorical) ones. Appropriate models of understanding the history were influenced by the dominant of the social consciousness of a certain era, in which the fundamental issues of the historical human being were raised. The core of the conceptual architectonics of the historiosophy of the modern time is the theory of historical progress. It was originally understood by the ancient Greek thinkers, the Sophists. In general, historiosophema of the progress in antiquity was far from determinant cogitative construction, as the history was not considered as an ontological reality: the being was strongly linked with nature, the Cosmos, with their inherent cyclical rhythm.

In the Middle Ages, the "Sacred Cosmos" of the ancient is replaced by the "sacred history", which uniqueness and originality of the events added value to the individual life, encouraging the human to actively seek for salvation. The history acquired linear, irreversible nature that did not accept the return of the past and suggested the "end of times", "abolition" of history with the advent of the Kingdom of God. Nevertheless, the "idea of history", which arose within the medieval Christian worldview, was extremely important for the development of a rationalist worldview. Rationalism was the ideological environment, where the fundamental bases of modern philosophy changed: from a transcendent God to the immanent substance.

The paradigm of progress (Herder, Turgot, Condorcet) was established as a conceptual dominant of the historiosophical discourse of the modern time, but this did not mean that the philosophy of history moved in the direction of the theoretical monism. It often correlated with other models of reconstruction of the objective historical reality contained in historiosophical thriftbox of the mankind (cyclical concept by G. Vico). However, the prevailing doctrine was that of historical progress that had empirical limitations. This led to the fact that the history was losing integrity, unity and meaning with its comprehension.

The merit of raising the issue of progress that varies from the empirical criteria belongs to the outstanding representatives of classical German philosophy, starting from Kant. They searched for criteria of progress in the field of 
consciousness, and the human was linked not only to empirical, but also to transcendental events of history in this regard. Problematics of history has been considered from the inside, from the point of view of the subject of history $-\mathrm{a}$ human, or rather, modifications of their consciousness.

\subsection{Importance of the Problem}

Philosophy of the XX century rebelled against the hypertrophy of rationality and abstract rationalism, which was insolvent against the demands of life; emphasis was placed on non-rational elements (Nietzsche's "will to power", Scheler's similar "rush", Freud's "unconscious", "existence" of Heidegger, Jaspers and Sartre). But it can't be described as anti-modernist, i.e. completely breaking the tradition of classical philosophy. Philosophical revision that began with a protest against the rationalistic harmonization of the world was justified, because it aimed at the protection of life. But since it "marched" to annihilate the mind, the whole context of the struggle changed - alternative mindset lost its advantages. It didn't overcome the flatness and abstract of rationalism, but only played off one abstract basis against another. Uncompromising struggle against the repressiveness of the mind led representatives of several schools of thought to the approval of the absolute meaninglessness of history, its hostility to the human (the Frankfurt School - T. Adorno, M. Horkheimer, "New Philosophy" - J.-M. Benoist, B.-H. Levy).

Orientation to a radical revision of modern philosophy was not the only one. It stood against the line for constructive rethinking of the philosophical classics tradition associated with the realization of possibilities and limits of competence of the mind. Constructive debate with representatives of classical philosophy was carried out by neoKantians (W. Windelband, H. Rickert), neo-Hegelians (R.J. Collingwood, B. Croce), neo-Positivists (B. Russell, K. Popper), neo-Thomists (J. Maritain, E. Gilson) and neo-Protestants (R. Niebuhr, P. Tillich). The coexistence of two opposite orientations in the Western philosophy of $X X$ century is a testament to the fact that it is a philosophy of postmodern rather than anti-modern, the substantive core of which is essential pluralism.

As a result, the historiosophical discourse of modernity is characterized by diversity, the coexistence of different paradigms. Constant, traditional schemes (historiosophemas of providentialism, progress, cyclism) are combined with non-traditional (psychoanalytic, structuralist, anthropological, metahistorical) matrices of understanding of socio-historical reality.

\section{Methods}

\subsection{Methodological "tools" of a historiosophy}

The paradigmatic unit of historiosophy - "historiosophema" - is suggested as the basis of methodological description of historical knowledge.

The definition of "historiosophy" was first used by the Polish philosopher Augustus Cieszkowski in 1838 in his doctoral thesis "Prolegomena to the historiosophy". It named Hegel's conception of world history as historiosophy (Butakov, 2005).

Since the second half of the XIX century, the historiosophy was understood as the tradition of comprehension of the historical process deriving from Hegel. It appeared that this process was caused by one main root cause, was objectively conditioned, had a one-way path of movement, the homogeneous nature for the whole of humanity and could be rationally knowable (Gulyga, 2008). This tradition was defined as the classical philosophy of history. It retreated "...within the desire to develop a common historical worldview understood as a philosophical elucidation of the principles of the history and principles of knowledge of history" (Kukartseva and Megill, 2006).

At the turn of XIX-XX centuries, the classical philosophy of history became the target of criticism from representatives of neo-Kantianism, neo-Positivism, "philosophy of life". In the criticism of Hegel's philosophy of history of classical type, the so-called critical philosophy of history has developed. Its ideological founders were G. Simmel, G. Rickert, W. Dilthey. They believed that the philosophy of history should be free of explaining the historical being through one main root cause, of claims for an understanding of its objective meaning. "Modern philosophy of history, - the consistent adherent of the critical philosophy of history R. Aron noted, - begins with the rejection of Hegelism" (Aron, 2000).

Critical philosophy of history has rejected the idea of the action of one main root cause in the history, of the homogeneous nature of the historical process, as well as faith in its ultimate goal, as a priori structure of the human mind that lacks sufficient evidence in an objective reality (Rusakova, 2002).

A particularly important role in the development of a new type of philosophy belongs to Russian thinkers of the turn 
of XIX-XX centuries and especially to N.I. Kareev, N.A. Berdyaev, V.V. Zenkovsky.

N.I. Kareev understood historiosophy as the doctrine of the general principles of reconstruction of the holistic historical process. He included the doctrine of the laws of the historical process and of social ideals into its subject, and used the methods of anthropology, sociology and psychology in interpreting historical being (Kareev, 1996). This version of the subject of historiosophy has not received further development in the Russian philosophy of history of the early XX century. N.A. Berdyaev and V.V. Zenkovsky offered a different version of historiosophy.

Historiosophy for N.A. Berdyaev is a special cogitative tradition, a special approach to interpretation of the history associated with raising of certain issues. His historiosophy is fundamentally anthropological and eschatological. The issue of the tragic dialectic of free human spirit takes the central place in it (Berdyaev, 1990).

According to interpretation of N.I. Berdyaev and V.V. Zenkovsky, historiosophy is a kind of philosophical reflection on the history that is characterized by an increased focus on the problems of ratio between generally universal and individual national in history, on the construction of eschatological images of the future (Berdyaev, 1990; Zenkovsky, 1991).

This interpretation of the philosophy of history has become popular among modern Russian historians and philosophers. At that, the top issues that are the subject of a special analysis include "Russian idea" and opposition "Russia - the West" (Groys, 1992; Karasev, 1992; Novikova and Sizemskaya, 1997).

\subsection{Methodological position of the author}

This paper provides one version of the subject content of historiosophy. Range of fundamental historiosophical issues is defined as follows. These are the issues of the ontological status of history (the "what" of the history), of the mechanisms of its functioning (the "how" of the history), of its direction (the "where" of the history), of its unity and multiplicity (the "how much" of the history), of its spatiotemporal certainty (the "where" and the "when" of the history). All the variety of these issues that sound in the context of philosophical reflection concerning the historical process comes together to a focus in the formulation of the problem of the meaning and purpose of history (Lebedev, 2013).

It is emphasized that the paradigmatic foundation of historiosophy - "historiosophema" - has undergone some changes depending on the ideological dominant of a particular historical era. Historiosophema of socio-historical cyclicality dominated in antiquity, providential historiosophema triumphed in the Middle Ages, historiosophema of a social progress - in modern times, and in the postmodern era the public consciousness is dominated by a post-classical science, which recognizes the coexistence of rational and irrational forms of spiritual experience, which has led to formation of historiosophical algorithm of diversity based on the correlation of constant, traditional schemes (cyclism, providentialism, progress) with non-traditional (psychoanalytic, structuralist, anthropological) matrices of understanding of socio-historical reality.

Thus, the attention should be focused on the existence of different historical types of historiosophy, methods of philosophical understanding of the historical being. The emergence of modern, postmodern historiosophical discourse is associated with intellectual rebellion against rational progressivist general historical theories of modern times with their focus on holistic, homogeneous vision of the world. Orientation to holistic, completed vision of the world (global explanatory schema) resulted in the loss of a human as an individual and personality. The meaning of world history turned out to be not for them and not about them.

\section{Results}

\subsection{The origins of Western philosophy of history}

Modern historiosophical thinking is formed as the result of a long spiritual movement. The core of the conceptual architectonics of the historiosophy of the modern time is the theory of historical progress. It was originally understood in the Western philosophy by the ancient Greek thinkers, the Sophists. In general, historiosophema of the progress in antiquity was far from determinant cogitative construction, as the history was not considered as an ontological reality: the being was strongly linked with nature, the Cosmos, with their inherent cyclical rhythm. The embodiment of all the highest values - Mind, Kindness, Justice, Beauty, Harmony and Order - was live Cosmos, not only intelligible but also sensuously perceptible. This prevented the consideration of human history as distinct from the natural area of being. The destiny of a human as a microcosm of the human race as a whole was directly dependent on the processes taking place in the macrocosm. Such a worldview argued the dominance of cyclic concepts in philosophy.

In the Middle Ages, the "Sacred Cosmos" of the ancient is replaced by the "sacred history", which uniqueness and 
originality of the events added value to the individual life, encouraging the human to actively seek for salvation. The history acquired linear, irreversible nature that did not accept the return of the past and suggested the "end of times". Comprehension of the meaning of history was based on the universal doctrine of divine providence, in the context of which the idea of progress was extended only to the spiritual life focused on salvation, since the presence of the divine providence entailed the "abolition" of history, its "end" with the advent of the Kingdom of God. Nevertheless, the "idea of history", which arose within the medieval Christian worldview, was extremely important for the development of a rationalist worldview. Representation of the one God (rather than many gods in mythology), who created a single world (and not many worlds), was consistent with the idea of the universal history of the human race. Stripped of religious shell, this idea was the starting point of conceptualization of the world history and thought patterns of modern times, mindsetting the actual philosophy of history. In addition, the concept of linear history formulated in Christian theology has played a huge role in the development of classical historiosophical theories of social and historical progress.

\subsection{Creation of the Modern historiosophical space}

Transformation of historiosophical space associated with bringing the theory of progress into focus was due to the fact that with the collapse of the medieval paradigm of world and history, a purely secular value system came to the fore, manifested in secularization of views - both on the nature and society. The "father of modern philosophy", Descartes (1596-1650), greatly contributed to this tectonic shift, as he sought to free the world and people's lives from the secrets and mysterious forces, and affirm faith in the unlimited possibilities of the human mind. The value of the rational was not that every human is endowed with reason, but that reason is able to give them spiritual freedom, lead to understanding the nature of the world and its laws, which can serve as a reliable basis for the transformation of reality. That is why rationality is synonymous with human activity, independence, individual freedom, which appeared to be not just compatible with the need, but also the experience of necessity. Whatever one makes of the reason, they were endowed with the status of sovereignty and ideally interpreted as distanced from things, as if remotely watching and exploring them, while not determined by any prerequisites other than the properties and characteristics of the studied objects.

Rationalism was the ideological environment where the fundamental bases of philosophy changed: from the transcendent God to the immanent substance (eternal and unchanging, self-sufficient and self-identical basis of the world). Philosophical substantialism significantly minimized the role of God and sought to find the basis of all things in the world, to explain the world from inside. This formula of substantialism was clearly expressed by Spinoza (1632-1677), who identified God with the substance. He merged God and the substance into one concept. God is not above nature, not the Creator outside the nature. He is right inside it as its immanent reason. Thus, Spinoza rejected a personal God and understood him as the universal cause of the world. Substance is unchanged, only its modus, individual things are changing. At the rigidly held opposition of the immutable essence (substance) to volatile existence (modus), history could not be a worthy subject of philosophical thinking: it had nothing significant and substantial.

In contrast to Spinoza's theory of a single substance, Leibniz (1646-1716) argued that there were an infinite number of substances, which he called monads (indivisible primary mental elements of the true, intelligible world). Each monad has a "history", i.e. the activity of the monad is deployment of some kind of built-in program, which Creator had originally harmonized with programs of other monads. According to the law of the internal development of monads, each of its further states can't be identical to the previous one. It contains both all of its future and all of its past. Leibniz monad brought the concept of personality, link between the singular and integrated consciousness, inner necessity and universality of the world, as well as historical development. However, these findings have evolved slowly and appeared later.

Revision of the philosophical foundations of substantialism began with Kant (1724-1804) - the founder of German classical philosophy, who for the first time had the cognizer as the subject of study, rather than the cognized substance. He particularly singled out the transcendental component in the structure of the cognizer. Kant called his philosophy transcendental, as he proceeded from recognition of special value for philosophical knowledge of priori ideas of reason that reported feasibility to the cognized object. Kant's transcendent views were not deprived of historicism, but provided the speculative, priori construction of philosophy of history without relying on empirical data, where the scale of history was taken not from itself, but from the mind.

Backed by a wise idea of Spinozism about the total presence of universe at every point of its single reality, the Leibniz doctrine of the constant elevation of monads that follow their own internal laws, and Kant's position on the selfknowledge of the mind, Hegel (1770-1831) created the great theory of the dynamics of historical being (Troeltsch, 1994). Although Hegel rejected the "transcendental philosophy" term, his doctrine as a whole represents the completion of the transcendental-philosophical consciousness deriving from Kant. Hegel speaks of human history, which replaced the 
substance, as of a transcendental subject. Substance as the subject is defined as self-developing and self-moving, which allowed Hegel to deduce the dialectical identity of the logical and historical. After completing the review of philosophical substantialism, Hegel came to pan-historism. He subdued not only a human, but also God to the history - God was created by history.

Adoption of the paradigm of progress as a conceptual dominant of the historiosophical discourse of the modern times did not mean that the philosophy of history moved in the direction of the theoretical monism. It often correlated with other models of reconstruction of the objective historical reality contained in historiosophical thriftbox of the mankind.

To some extent, the choice of certain doctrines as a priority was affected by certain historical conditions of development of various regions of Europe. In XVII-XVIII centuries, Britain, France, Rhineland Germany became a new gravitational center of European economics and politics, where the absolute idea of progress triumphed in the spiritual searches, which was expressed in the adoration of continuous, progressive historical development. In these countries, which were widely covered by the Enlightenment, the idea of a straight line, forward movement of history was accompanied by contempt for the "dark" past of mankind (antiquity and the Middle Ages). Cartesians Perrault, Fontenelle and Houdar de la Motte strongly rebelled against the absolute authority of antiquity and, comparing the Homer's country with France, found that the former was similar to the village, while its heroes - to the rough vulgar. Ancient times, in their opinion, were wild, immoral and full of all kinds of prejudices. During this period in Italy, the fading culture of the Renaissance and disintegration of urban republics became a prologue to profound national decline. Educational movement in conditions of political fragmentation was not united, it divided into separate loosely connected groups, and was complicated by the fact that here the power of the papacy was felt much more strongly than in other Catholic countries. These circumstances made rationalism on Italian soil especially pathetic, which is reflected in the philosophy of history by recognition of the idea of only a relative progress, like by G. Vico (1668-1744), who developed it as part of a cyclical conception (Vico, 1994). His ideas of the continuous development of mankind are not related to contempt for ancient and medieval history: he defines the childhood of the human race as "the eternal beauty". Moreover, he learned the laws of social development on the ancient history material.

In contrast to the Italian philosopher Vico who adhered to the idea of the relative progress, the representative of the German Enlightenment, Johann Herder (1744-1803), developed the idea of absolute progress (Herder, 1977). Early Kant, Spinoza and Leibniz had a strong influence on the formation of Herder's views.

Historiosophema of Herder's absolute progress was based on the fact that the historical development had an ascending and continuous nature, which determines its direction to the maximum. Human society is a self-developing unit, each element of which is related to the previous and next. Every nation uses the achievements of its predecessors and prepares the ground for the next generation.

Overall, progress in the Enlightenment philosophy of history was presented as an empirical fact, when thinkers were satisfied with external indicators of progress, i.e. indicators of accomplished sociocultural changes. As part of the empirical historiosophy of the enlighteners, substantial progress in understanding the objective historical reality was achieved: Herder brought in the idea of pluralism and the variance of the history, the statement of inherent value and independence of all existed and existing national cultures; Turgot and Condorcet proposed the concept of human development by stages; Montesquieu proposed the idea of improving the laws and public institutions as a factor of historical movement. However, the empirical limitations of the doctrine of progress led to the fact that the history was losing integrity, unity, meaning and purpose with its comprehension.

The merit of raising the issue of progress that varies from the empirical criteria of the enlighteners belongs to the outstanding representatives of classical German philosophy. They searched for criteria of progress in the field of consciousness, and the human was linked not only to empirical, but also to transcendental events of history in this regard. Problematics of history has been considered from the inside, from the point of view of the subject of history (a human), or rather modifications of their consciousness.

Kant began to develop activity concept of consciousness, the key in the classical German philosophy. When reviewing the structure of consciousness, he was first to point out the distinction between reason and mind. Reason, which has access only to the world of experience, organizes only a causal connection (which was typical of the Enlightenment) and is not able to carry out a comprehensive synthesis or, in the terminology of Kant, a higher unity. This kind of unity can only be achieved with the mind, which has access to what is beyond the experience. Mind is the highest ability of the subject, which directs the activities of the reason, sets goals for it. When separating a goal-setting function of the mind, philosophical understanding of history intended to indicate the goal of the human activity, the purpose for the human race to be in history - a teleological view of history (Shaymuhambetova, 1995).

Kant did not deny the fruitfulness of the approach of empirical historicism of the enlighteners, but proposed an entirely different approach - the approach of transcendental historicism. It was based on a teleological view of history, 
which was determined by the Kant's recognition of the special value of priori ideas of the mind that allowed to achieve the highest synthesis in interpreting the history.

Appealing to teleologism within transcendental historicism led to the explanation of "historical unconscious" as a phenomenon of mismatch between the objectives and results of historical events, as indicated by Vico. According to Kant, people realized their goals in the history, while at the same time moving to an unknown historical goal. This idea was taken up and developed by Schelling (1775-1854), whose work "System of Transcendental Idealism" constituted history as the relationship between the unconditioned individual on the one hand and historical necessity on the other. All individuals are endowed with free will, and the human world creates consciously, but it results in something that nobody planned, i.e. something unconscious (Gulyga, 1994).

Teleologism, as a main element of the transcendental historicism, fully penetrated the historiosophical constructions of Hegel (Perov and Sergeev, 2000). Everything in history finds its meaning only by reference to the goal both to a general ultimate goal of the history and to associated specific objectives of each historical stage. The purpose of the historical development is the progress of spirit in realization of freedom.

In parallel with the German philosophical and historical thinking, a quite different in nature Anglo-French positivist thinking has evolved. Positivism denied the ideas of "German classics" on progress in the form of self-transcending consciousness - ideas that were built without any reference to the laws of nature, and in accordance with which the steplike movement of nations was defined each time as the individual specification of the mind (Panarin, 1999). Instead of Hegelian metaphysics of the spiritualistic monism, monism of the positive was introduced, i.e. of the science method. Metaphysics and a priori were denied and only experience was admitted. Positivism as a whole has grown from ideas of Anglo-French Enlightenment, also extending its idea of progress as an empirical fact. Positivist philosophy of history was characterized by fundamental sociocentrism; the problem of the society took the key place in it.

Marxism was the most important kind of radical philosophy of progress, along with positivism in the XIX century. In K. Marx's historiosophy, progress was associated with the development of the productive forces in the first place.

Despite the fundamental differences between the enlighteners, idealists, positivists and Marx in constructing the goal of historical development, they had one essential thing in common: anticipation of the future was carried out on the basis of the abstract rationalist models, because classical science, which recognizes only rational forms of development of the world, dominated the social consciousness in modern times.

Rationalist theories of general history of modern times, which based on the concept of progress, were directed exclusively to base the idea of the unity of history. The idea of unity in its rationalistic interpretation was seen in the focus, patterns and sustained process of world history, and eventually led to the justification of uniformity, sameness of the events and historical destinies of nations (Smolensky, 1996). Rationalist historiosophical intention to homogeneity of the world history was set by the philosophy of Descartes, which declared sovereignty of thought in "Cogito ergo sun". Descartes endowed human knowledge with a certain autonomy, which contributed to a sort of withholding it from the world; while the link of human cognitive activity to the world in which they live, if not denied, was neglected by the philosopher. This resulted in the recognition of the mind as not only possible, but also having the right to establish the concepts in isolation from reality and its specificity, create imaginary world. Recognition of the participation of consciousness in the construction of the world events gave birth to its (consciousness) aiming to improve and change everything according to the rules of logic. Gap between the history and mind, and classification of the mind as some constant human nature (substance) led to the perception of the unity of the historical development of its consistency and mindset to understand the global meaning of human history, involving uniquely predetermined main path of progress. Orientation to holistic, completed vision of the world (global explanatory schema) resulted in the loss of a human as an individual and personality. The meaning of world history turned out to be not for them and not about them.

\subsection{Postmodern historiosophical discourse}

"Return" of the human to history is carried out in the post-modern historiosophy, and the merit for this largely belongs to a founder of phenomenological philosophy Edmund Husserl (1859-1938), despite his unconditional connection with the mindset of modern times. Reorientation of Western philosophy on the issue of the principles of human understanding of the world found expression in phenomenology. Husserl was the one who made a statement that the basis of all our judgments about the world is activity of the subject making these judgments, that the world is given to a human only in the acts of their spiritual life, their acts of consciousness. Husserl provides different, in comparison with classical philosophy, understanding of the relationship of consciousness to the outside world: the subject of Husserl's philosophy is interested not in the world as is, but in its meaning and significance for the subject (Hyubsher, 1994). The philosopher introduces the concept of "phenomenological reduction". Its meaning is implicit assumption that the world around us is a creation of 
our mind. Of course, the outside world exists objectively, but for us it begins to have meaning only through its realization. The world that we perceive becomes the world within us. Structuring of the world in our minds is impossible without recourse to everyday contexts of consciousness, and Husserl therefore proposed the concept of "lifeworld".

A cognizer was "back" to history through the everyday reality - a new dimension to the human world. Appeal to everyday life has become an imperative for both the Husserl's philosophy, who searched the base for rational, scientific consciousness in it, and the "philosophy of life" (Friedrich Nietzsche, Dilthey), which rebelled against the repression of mind and generally against the tradition of classical philosophy, which justified the idea of the substantial unity of history. Increased attention to everyday life is a sign of a paradigm shift: classical to post-classical, postmodern (Kozlova, 1992). The collapse of the crystal castle of philosophical abstractions and weaving of a particular individual into an empirical lace of the everyday were the main problem to be solved within the framework of one of the largest and most influential philosophies of the XX century - existentialism, the philosophy of existence (Karl Jaspers, M. Heidegger). Representatives of this thinking borrowed many ideas from the "philosophy of life" and Husserl's phenomenological method - description of conceptualization. The idea of "existential historicity" about human involvement in the flow of events of history led to the conclusion of its incompleteness, inconclusiveness. The principal incompleteness of the history was projected both to the past, which each time was redefined as new, and to the future, which appears in its variability, "openness" to the spectrum of possibilities. A human does not cognize the meaning of history that exists outside of them, they construct it. There is only a change in alternating meanings of history. Such an approach is inherent to philosophical hermeneutics, the founder of which is H.-G. Gadamer, a follower of M. Heidegger. Gadamer expressed the fundamental idea of hermeneutics in the following formula: one person can't cognize and report the truth, the process of finding meaning ("essence") is inseparable from self-understanding of each interpreter (Sidortsov, 2010). According to the existential-hermeneutic mindset, a human included in the flow of events of history is not able to objectively and in final form understand its semantic content. This, in turn, gave rise to the idea of multiplicity of semantic pictures of the past. Thus, instead of a global meaning of history, pluralism of its semantic interpretations was admitted.

Focus on the existence rather than on the essence (unified substantial basis), an increasing movement of interests to the area of everyday life, where the fate of a human was determined, was due to the crisis of state of mind generated by the First World War. In circumstances where rationally organized activity of millions of people was aimed at destruction, an important feature of the shift in social consciousness was spread of irrationalism - disbelief in the possibility of a human mind. Before, the truth was searched for in the mind, now it was found in the opposite: in the preconscious, unconscious, subconscious. The irrational forms of spiritual experience, along with the philosophy of existence, was studied by psychoanalytic philosophy established by S. Freud, who saw the sets of unconscious motivation (desire for self-affirmation and sexual desire) as not just the condition for most mental actions of a human, but also for all the historical events; and by philosophical anthropology of M. Scheler with its antithesis of "rush and spirit", where the "spirit" is what makes us human, superimposing an irrational core, the "rush", which is not just a synonym of unbridled flow of life, but also a succinct definition of the actual progress of history in all of its realities. If the philosophy of the XX century in connection with the uprising against the hypertrophy of rationality and abstract rationalism, insolvent against the demands of life, was focused only at non-rational elements (Nietzsche's "will to power", Scheler's similar "rush", Freud's "unconscious", "existence" of Heidegger, Jaspers and Sartre), it could have been described as antimodernist, i.e. completely breaking the tradition of classical philosophy. Philosophical revision that began with a protest against the rationalistic harmonization of the world was justified, because it aimed at the protection of life. But since it grew into a total accusation and "marched" to annihilate the mind, the whole context of the struggle changed - alternative mindset lost its advantages. It didn't overcome the flatness and abstract of rationalism, but only played off one abstract basis against another. Uncompromising struggle against the repressiveness of the mind led representatives of several schools of thought to the approval of the absolute meaninglessness of history, its hostility to the human (the Frankfurt School - T. Adorno, M. Horkheimer, "New Philosophy" - J.-M. Benoist, B.-H. Levy).

Orientation to a radical revision of modern philosophy was not the only one. It stood against the line for constructive rethinking of the philosophical classics tradition associated with the realization of possibilities and limits of competence of the mind. Constructive debate with representatives of classical philosophy was carried out by neoKantians (W. Windelband, H. Rickert), neo-Hegelians (R.J. Collingwood, B. Croce), neo-Positivists (B. Russell, K. Popper), neo-Thomists (J. Maritain, E. Gilson) and neo-Protestants (R. Niebuhr, P. Tillich) (Gubman, 1991). The coexistence of two opposite orientations in the Western philosophy of XX century is a testament to the fact that it is a philosophy of postmodern rather than anti-modern, the substantive core of which is essential pluralism (Lebedev, 2014). 


\section{Discussion and Conclusions}

As a result, the historiosophical discourse of postmodernity is also characterized by diversity, the coexistence of different paradigms. Constant, traditional schemes (historiosophemas of providentialism, progress, cyclism) are combined with non-traditional (psychoanalytic, structuralist, anthropological) matrices of understanding of socio-historical reality. In the latter, a subject of research is either the psychology of outstanding leaders that sweep the world into an unexpected plane of cultural development (psychoanalysis) or the instinctive nature of a human straining after breaking the shackles of civilization (philosophical anthropology), or some constantly renewed structures of the historical process (structuralism).

As part of diversity algorithm of the postmodern historiosophy (correlation of traditional and nontraditional paradigms), which involves the pairing of the idea of the unity with the idea of multiplicity of meaning pictures of the past, it becomes possible to connect such properties of the history as the unity and qualitative diversity (unity in diversity).

Certain dynamics of understanding the history of the Western historiosophy is recorded in Table 1. Its data clearly show that the philosopher does not deliberately invent the theoretical matrices of understanding the history, but finds it in the conscious of the contemporary era and uses to construct meaningful structures of historical movement. In accordance with the dominant of the social consciousness of a certain era - in the framework of a theoretical understanding of history - its "dominant" historiosophema emerges.

Table 1. Conceptual models of comprehension of history

\begin{tabular}{|c|c|c|c|c|}
\hline Parameters & $\begin{array}{l}\text { Antique model (IX cent. BC - } \\
\text { middle of V cent.) }\end{array}$ & $\begin{array}{l}\text { Middle Age model } \\
\text { (middle of V cent. - } \\
\text { middle of XVII cent.) }\end{array}$ & $\begin{array}{l}\text { Modern model (middle of } \\
\text { XVII cent. - XIX cent.) }\end{array}$ & $\begin{array}{l}\text { Postmodern model } \\
\text { (XX cent. - beginning } \\
\text { of XXI cent.) }\end{array}$ \\
\hline $\begin{array}{l}\text { Dominant form of social } \\
\text { consciousness }\end{array}$ & $\begin{array}{l}\text { Significant impact of } \\
\text { mythology }\end{array}$ & Religion & $\begin{array}{l}\text { Classical science, which } \\
\text { recognizes only rational } \\
\text { forms of spiritual } \\
\text { experience }\end{array}$ & $\begin{array}{l}\text { Post-classical science } \\
\text { recognizes the } \\
\text { coexistence of rational } \\
\text { and irrational forms of } \\
\text { spiritual experience }\end{array}$ \\
\hline $\begin{array}{l}\text { Trajectory of historical } \\
\text { movement }\end{array}$ & $\begin{array}{l}\text { Cyclic model - cycles were } \\
\text { understood as the cycle of } \\
\text { fruitless repetitions, without } \\
\text { qualitative changes }\end{array}$ & $\begin{array}{l}\text { Linear model - upward } \\
\text { movement: from the fall } \\
\text { of man to the Kingdom of } \\
\text { Heaven }\end{array}$ & $\begin{array}{l}\text { Linear model - upward } \\
\text { movement: from the } \\
\text { primitive to the higher } \\
\text { forms of social being }\end{array}$ & $\begin{array}{l}\text { Spiral model - } \\
\text { movement is cyclic, } \\
\text { but eventually to the } \\
\text { progress }\end{array}$ \\
\hline $\begin{array}{l}\text { Ontological status of } \\
\text { history }\end{array}$ & $\begin{array}{l}\text { Being was strongly linked with } \\
\text { nature. A human dissolved } \\
\text { themselves in Cosmos, and } \\
\text { Cosmos and nature - in } \\
\text { themselves. History was not } \\
\text { considered as an ontological } \\
\text { reality }\end{array}$ & \begin{tabular}{|l|} 
History has gained \\
ontological status, but \\
was perceived as "Sacred \\
history", i.e. the scope of \\
manifestation of God. \\
Profane history was not \\
viewed as a true being \\
\end{tabular} & $\begin{array}{l}\text { The view of history as an } \\
\text { independent area of } \\
\text { being was asserted. } \\
\text { However, it was limited } \\
\text { only to the social area }\end{array}$ & $\begin{array}{l}\text { History is intersection } \\
\text { of two planes of } \\
\text { being: the earthly and } \\
\text { the heavenly, the } \\
\text { mundane and the } \\
\text { sacred }\end{array}$ \\
\hline $\begin{array}{l}\text { Horizon of historical } \\
\text { space }\end{array}$ & $\begin{array}{l}\text { Idea of world history } \\
\text { emerged. Unity of the world } \\
\text { history was created at the } \\
\text { cost of limiting it only to the } \\
\text { Greco-Roman world (unity is } \\
\text { in uniqueness) }\end{array}$ & $\begin{array}{l}\text { Exclusivity of the Greco- } \\
\text { Roman history gave way } \\
\text { to the inclusion in the } \\
\text { world history of all nations } \\
\text { without distinction of } \\
\text { ethnicity, subject to their } \\
\text { acceptance of Christianity } \\
\text { (unity is in its uniformity) }\end{array}$ & $\begin{array}{l}\text { Focused, logical and } \\
\text { progressive world } \\
\text { historical process at the } \\
\text { sameness of events and } \\
\text { historical destinies (unity } \\
\text { is in uniformity) }\end{array}$ & $\begin{array}{l}\text { In world history, such } \\
\text { its properties are } \\
\text { synthesized as unity } \\
\text { and qualitative } \\
\text { diversity (unity is in } \\
\text { diversity) }\end{array}$ \\
\hline $\begin{array}{l}\text { Source of historical } \\
\text { movement }\end{array}$ & $\begin{array}{l}\text { Laws of nature and the } \\
\text { Cosmos }\end{array}$ & Divine providence & Social laws & $\begin{array}{l}\text { Interaction of the bio- } \\
\text { cosmo-socio-sphere } \\
\text { factors and the divine } \\
\text { will }\end{array}$ \\
\hline
\end{tabular}

\section{References}

Aron, R. (2000). Favorites: Introduction to the philosophy of history (pp. 11). Moscow: Publishing house "PER-SE"; Saint Petersburg: Publishing house "Universitetskaya kniga".

Berdyaev, N.A. (1990). The meaning of history (pp. 177). Moscow: Publishing house "Mysl". 
Butakov, J. (2005). Historiosophy. Retrieved January 23, 2015, from http://pravaya.ru/govern/392/2096

Vico, G. (1994). Origins of New Science Surrounding the Common Nature of Nations (pp. 637). Moscow: Publishing House "REFLbook"; Kiev: Publishing house "ris".

Herder, J.G. (1977). Reflections on the Philosophy of the History of Mankind (pp. 703). Moscow: Publishing house "Nauka".

Gubman, B.L. (1991). The meaning of history. Sketches of modern western concepts (pp. 192). Moscow: Publishing house "Nauka"

Groys, B. (1992). Search Russian national identity. Philosophy questions, 9, 52-60.

Gulyga, A.V. (1994). Schelling. (3nd ed., pp. 89-91). Moscow: Publishing house "Soratnik".

Gulyga, A.V. (2008). Hegel (pp. 263). Moscow: Publishing house "Molodaya Gvardiya".

Zenkovsky, V.V. (1991). The history of Russian philosophy (Vol. 1, pp. 11-30). Leningrad: Publishing house "EGO".

Karasev, L.V. (1992). Russian idea (symbolics and sense). Philosophy questions, 8, 92-104.

Kareev, N.I. (1996). Philosophy, History and Theory of Progress. Article. In Essay on the history of Russian philosophy: An Anthology (pp. 219-233). Moscow: Publishing House of Institute of philosophy of the Russian Academy of Sciences.

Kozlova, N. (1992). Sociology of Everyday Life: a reassessment of values. Social Sciences and Modernity, 3, 47-56.

Kukartseva, M.A., \& Megill, A. (2006). The Philosophy of History and Historiology. Verge match. Istoriya and modernity, 2, 24-46.

Lebedev, V. E. (2013). Conceptual models of comprehension of history in the context of dynamics of the western thinking. European Social Science Journal, Vol. 2, 8(35), 396-405.

Lebedev, V. E. (2014). Modeling of history in dynamics of east and western thinking (pp. 200). Ekaterinburg: Publishing House of Ural Federal University.

Novikova, L.I., \& Sizemskaya, I.N. (1997). Russian philosophy of history: Course of lectures (pp. 327). Moscow: Publishing House "Magistr".

Panarin, A.S. (1999). Philosophy of history (pp. 365-366). Moscow: Publishing House "Gardariki".

Perov, Yu.V., \& Sergeev, K.A. (2000). "Philosophy of History" Hegel from substance to historicity. In Article. G.V.F. Gegel. Lectures on the Philosophy of History (pp. 5-53). Saint Petersburg: Publishing House "Nauka".

Rusakova, O.F. (2002). Historiosophy: interpretation of the subject and typology. Article. Scientific Year-Book of Institute of Philosophy and Right of the Ural Office of the Russian Academy of Sciences, 3, 3-28.

Sidortsov, V.N. (2010). History methodology: course of lectures (pp. 207). Minsk: Publishing House of Belarusian State University.

Smolensky, N.I. (1996). Whether the general historical theory is possible? Modern and Contemporary History, 1, 3-17.

Troeltsch, E. (1994). Historicism and its problems. The logical problem of the philosophy of history (pp. 720). Moscow: Publishing House "Yurist".

Hyubsher, A. (1994). Thinkers of our time. Reference book on philosophy of the West of the XX century (pp. 312). Moscow: Publishing house "Tsentr tvorcheskogo razvitiya".

Shaymuhambetova, G.B. (1995). Hegel and the East. Principles of the approach (pp. 134-135). Moscow: Publishing House of the "Vostochnaya Literature", Russian Academy of Sciences. 